\title{
How to avoid microaspiration? A key element for the prevention of ventilator-associated pneumonia in intubated ICU patients
}

\author{
Stijn I Blot ${ }^{1,2^{*}}$, Jan Poelaert ${ }^{3}$ and Marin Kollef ${ }^{4}$
}

\begin{abstract}
Microaspiration of subglottic secretions through channels formed by folds in high volume-low pressure poly-vinyl chloride cuffs of endotracheal tubes is considered a significant pathogenic mechanism of ventilator-associated pneumonia (VAP). Therefore a series of prevention measures target the avoidance of microaspiration. However, although some of these can minimize microaspiration, benefits in terms of VAP prevention are not always obvious. Polyurethane-cuffed endotracheal tubes successfully reduce microaspiration but high quality data demonstrating VAP rate reduction are lacking. An analogous conclusion can be made regarding taper-shaped cuffs compared with classic barrel-shaped cuffs. More clinical data regarding these endotracheal tube designs are needed to demonstrate clinical value in addition to in vitro-based evidence. The clinical usefulness of endotracheal tubes developed for subglottic secretions drainage is established in multiple studies and confirmed by meta-analysis. Any change in cuff design will fail to prevent microaspiration if the cuff is insufficiently inflated. At least one well-designed trial demonstrated that continuous cuff pressure monitoring and control decrease the risk of VAP. Gel lubrication of the cuff prior to intubation temporarily hampers microaspiration through sludging the channels formed by folds in high volume-low pressure cuffs. As the beneficial effect of gel lubrication is temporarily, its potential to reduce VAP risk is probably nonsignificant. A minimum positive end-expiratory pressure of at least $5 \mathrm{cmH}_{2} \mathrm{O}$ can be recommended as it reduces the risk of microaspiration in vitro and in vivo. One randomized controlled study demonstrated a reduced risk of VAP in patients ventilated with PEEP $\left(5-8 \mathrm{cmH}_{2} \mathrm{O}\right)$. Regarding head-of-bed elevation, it can be recommended to avoid supine positioning. Whether a $45^{\circ}$ head-of-bed elevation is to be preferred above $25-30^{\circ}$ head-of-bed elevation remains unproven. Finally, the routine monitoring of gastric residual volumes in mechanically ventilated patients receiving enteral nutrition cannot be recommended.
\end{abstract}

Keywords: Ventilator-associated pneumonia, Pneumonia, Micro-aspiration, Prevention, Infection

\section{Background}

Ventilator-associated pneumonia (VAP) remains a feared complication in intensive care unit (ICU) and high-risk surgical postoperative patients [1]. VAP is associated with substantial excess morbidity [2-4] and may suppress survival [5-9]. On average $10-20 \%$ of ICU patients ventilated for $>2$ days experience VAP [10]. However, VAP incidence may vary according to diagnostic approach. Broad-scaled initiatives to streamline definitions and

\footnotetext{
* Correspondence: stijn.blot@UGent.be

'Dept. of Internal Medicine, Faculty of Medicine \& Health Sciences, Ghent

University, De Pintelaan 185, 9000 Ghent, Belgium

${ }^{2}$ Burns, Trauma and Critical Care Research Centre, The University of

Queensland, Brisbane, Australia

Full list of author information is available at the end of the article
}

surveillance methods are necessary to allow fair benchmarking [11]. Incidence estimates may also vary with patients' risk profile and compliance with prevention measures, which remains an issue in many ICUs [12-16].

VAP prevention targets the main pathogenic mechanism, which is bacterial translocation from stomach and oropharynx to the lower respiratory tract. Within hours following endotracheal intubation pathogenic microorganisms colonize the oropharyngeal mucosal surfaces, dental plaque, sinuses, and stomach $[17,18]$. Accumulation of oropharyngeal secretions colonized with these pathogens occurs above the endotracheal tube (ETT) cuff. Microaspiration of these subglottic secretions might occur through an underinflated tracheal cuff or through

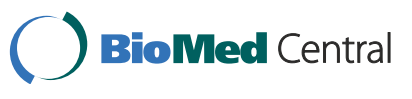


longitudinal folds in high volume-low pressure cuffs. Furthermore, a nasogastric tube may facilitate gastroesophageal reflux. Therefore, gastric juice may be aspirated into the lungs, provoking local inflammation $[17,19]$. Generally, the prevention of VAP is focused on reducing the exposure time, maintaining oral hygiene by antiseptic rinsing, and avoidance of microaspiration [20-22]. However, microaspiration seems decisive because it is unlikely that prolonged exposure or bad oral hygiene as such would arouse VAP in the absence of substantial microaspiration. Consequently, a lot of emphasis is given to avoidance or minimization of microaspiration [22]. Several preventive measures have been developed to decrease the risk of microaspiration. Although some of these successfully reduced microaspiration, their potential to reduce VAP is not always proven. The objective of this paper is to briefly review measures to avoid microaspiration of subglottic secretions and to evaluate their effectiveness in doing so and in preventing VAP.

\section{Review}

\section{Selection of the endotracheal tube}

In the 1960s cuffs of ETTs were made of red rubber. While these "high pressure-low volume" cuffs were successful in sealing the extraluminal airway, ischemic damage of the tracheal wall was an issue. Therefore these ETTs were soon replaced by ETTs with "high volumelow pressure" (HVLP) cuffs made out of polyvinyl chloride (PVC). In the past decades HVLP cuff ETTs experienced several changes in design, some of them with the primary aim to reduce the risk of microaspiration. Some of these will be mentioned hereunder.

\section{Endotracheal tube cuff material: polyurethane vs. PVC}

One of the disadvantages of the standard HVLP cuff is that the diameter of the cuff is bigger than the tracheal diameter. As such, only a low pressure is needed for inflation and for letting the cuff adapt to the shape of the trachea. With this concept, however, the cuff is not fully unfolded resulting in channel formation along the cuff. Through these channels microaspiration might occur.

Ultrathin polyurethane cuffs have been developed to minimize the channel size within folds of an inflated cuff. In an in vitro setup using a tracheal model with a $20 \mathrm{~mm}$ internal diameter, fluid leakage past the tube cuff was compared between a polyurethane cuff (cuff membrane thickness $7 \mu \mathrm{m}$ ) and four ETTs with a PVC cuff (cuff membrane thickness 50 to $70 \mu \mathrm{m}$ ) [23]. Fluid leakage was evaluated at cuff pressures of 10, 15, 20, 25, 30 and $60 \mathrm{cmH}_{2} \mathrm{O}$, and the amount of fluid leakage was recorded at 5,10 , and 60 minutes. Within the recommended target cuff pressure of $20-30 \mathrm{cmH}_{2} \mathrm{O}$, the polyurethane cuff was the only to effectively prevent fluid leakage past the cuff. In another in vitro study three types of polyurethane cuffed
ETTs were compared with three types of ETTs with a PVC cuff [24]. The amount of fluid leakage after $1 \mathrm{hr}$ was evaluated in three artificial tracheal models varying in internal diameter (16, 20, and $22 \mathrm{~mm}$ ). Overall, polyurethane ETTs prevented fluid leakage more efficiently than PVC cuffs $(\mathrm{p}<0.001)$. Similar observations were made in a benchtop study in which tracheal models were exposed to different levels of positive end-expiratory pressure (PEEP) [25].

Concerning clinical outcomes, the available data are scarce. A polyurethane cuffed ETT significantly reduced the risk of early post-operative pneumonia in high-risk cardiac surgical patients from $42 \%$ to $23 \%$ (adjusted odds ratio $0.31,95 \%$ confidence interval [CI] 0.13-0.77) [26]. In a randomized controlled trial, Mahmoodpoor et al. compared rates of VAP associated with three types of ETTs: a cylindrical polyurethane cuffed, a taper-shaped polyurethane cuffed, and a cylindrical PVC cuffed tube [27]. In a comparison with polyurethane cuffed tubes (both groups merged) and the PVC cuffed ETT, no difference in VAP could be observed ( $20 \%$ vs. $34 \%$, respectively; $\mathrm{p}=0.134)$. However, this study suffers several limitations. The study was likely to be underpowered and VAP was defined solely in accordance with the clinical pulmonary infection score thereby probably leading to overestimation of the true incidence.

\section{Endotracheal cuff shape: tapered vs. cylindrical}

Conventional ETTs have a cylindrical-shaped cuff. An ETT with a taper-shaped cuff was developed with the promise to better adapt to natural variations in the size of the trachea. Because of its tapered shape, this cuffs seals the trachea, at least at one point, without fold formation. An in-vitro study was able to demonstrate superior sealing capacity of these taper-shaped cuffs compared to cylindrical-shaped cuffs [24]. Additionally, they appeared to be equally effective in preventing fluid leakage as cylindrical-shaped polyurethane cuffed ETTs. Of note, in tracheal models with a larger diameter the favorable effect of taper-shaped cuffs over cylindrical-shaped polyurethane cuffs was greater. In a clinical bronchoscopy-controlled study in patients undergoing lumbar surgery, microaspiration of instilled methylthionium chloride was compared between taper-shaped PVC cuffs and barrel-shaped PVC cuffs [28]. After 30 minutes, following turning the patients in prone position, the barrel-shaped cuff showed descent of dye into the trachea in $20 \%$ of the patients. Contrariwise, after two hours of observation, no dye leakage into the trachea was observed with taper-shaped cuffs. To what extent the endotracheal tube with a taper-shaped cuff results in reduced VAP rates remains to be demonstrated.

\section{Subglottic secretions drainage (SSD)}

Another strategy to prevent microaspiration is to avoid accumulation of subglottic secretions above the cuff. 
ETTs for SSD can drain secretions through a separate dorsal lumen that opens directly above the cuff. A metaanalysis pooling 13 randomized controlled trials and encompassing 2442 patients demonstrated an overall risk reduction with use of SSD of 0.55 (95\% CI, 0.46-0.66) [29]. When only high quality trials were taken into account the effect remained statistically significant (risk ratio $0.54,95 \% \mathrm{CI}, 0.40-0.73$ ). Overall, the use of SSD was associated with a reduced ICU stay, decreased length of ventilatory dependence, and an increased time to first episode of VAP. Drainage can be successfully performed either continuously or intermittently [30].

\section{Gel lubrication of the cuff.}

Gel lubrication of the cuff prior to intubation is mainly done to smoothen the procedure. Yet, by doing so the channels along the cuff wall are plugged thereby blocking microaspiration of oropharyngeal secretions. Blunt et al. compared fluid leakage in lubricated and nonlubricated cuffs in a benchtop model with use of a static pig trachea model [31]. After $15 \mathrm{~min}$. all five nonlubricated cuffs leaked, while in none of the lubricated cuffs dye leakage was observed. Another in vitro study testing six different brands of ETTs revealed that in case of gel lubrication no dye leakage occurred in the 1 hr observation period [32]. In all six nonlubricated cuffs leakage became obvious within five minutes.

Microaspiration in lubricated vs. nonlubricated cuffs was evaluated in a double-blinded, randomized clinical study involving anesthetized patients undergoing extraction of wisdom teeth [31]. In all patients diluted blue food dye was instilled above the cuff after intubation. During the surgical procedure cuff pressure was maintained at $30 \mathrm{cmH}_{2} \mathrm{O}$ by a constant cuff pressure inflator. Microaspiration was evaluated by means of endotracheal aspiration after surgery and before extubation. Microaspiration was witnessed in $11 \%$ of lubricated cuffs vs. $83 \%$ of nonlubricated cuffs ( $\mathrm{p}<0.001)$. A similar approach of blue dye instillation was used in a prospective observational study involving tracheotomized patients with lubricated cuffs only [31]. The lubricated cuffs leaked after a median period of 48 hrs (ranging 24 to $120 \mathrm{hrs}$ ). From these studies it appears that microaspiration can be temporarily avoided by gel lubrication. Therefore, gel lubrication might be of value in short term-ventilated patients. However, any value in terms of pneumonia prevention remains unproven.

\section{Cuff pressure monitoring}

No cuff seals when insufficiently inflated. The recommended cuff pressure for HVLP cuffs ranges 20-30 $\mathrm{cmH}_{2} \mathrm{O}$. However, cuff pressure easily deviates outside this target interval due to pathophysiological and environmental circumstances, and body position changes
$[33,34]$. Devices to provide automated monitoring and adjustments of cuff pressure have been developed. In an initial randomized controlled trial these devices proved successful to maintain cuff pressure within the target limits, but no effect on VAP rate was observed [35]. It has been suggested that no difference in VAP rate was observed as randomization took place two days following intubation. In another randomized control trial, Nseir et al. also demonstrated that continuous cuff pressure monitoring was effective in maintaining the pressure within the target limits compared with manual control per 8 hours: $98 \%$ of measurements vs. $74 \%(\mathrm{p}<0.001)$ [36]. In addition, patients in the intervention group had a decreased risk for micro-aspiration of gastric contents and VAP (9.8\% vs. 26.2\%; $\mathrm{p}=0.032)$, thereby confining the controversial status of continuous cuff pressure monitoring as valuable to prevent pneumonia [37].

\section{Positive End-Expiratory Pressure (PEEP)}

Experimental studies with HVLP cuffs showed that, as airway pressures rise, the gas contained within the cuff is redistributed from the distal to the proximal cuff end. This results in a cone-shaped cuff in which the intracuff pressure is temporarily (during the inspiratory phase) higher than the cuff pressure during the expiratory phase. As such, positive pressure ventilation creates a 'self-sealing' effect by which tracheal occlusion is maintained despite airway pressure exceeding intra-cuff pressures [38]. Therefore it was hypothesized that PEEP could result in a better sealing capacity throughout the ventilation cycle, and as such reduce micro-aspiration. In a benchtop study Ouanes et al. demonstrated that microaspiration occurring within one hour decreased from 91\% with zero PEEP to $8 \%$ with $15 \mathrm{cmH}_{2} \mathrm{O}$ PEEP [39]. Similarly, also Pitts et al. observed that microaspiration decreased with higher levels of PEEP $(5,10$ or $15 \mathrm{cmH}_{2} \mathrm{O}$ ) [40]. In this study peak inspiratory pressure also was inversely associated with leakage volume but not anymore when PEEP was set at $15 \mathrm{cmH}_{2} \mathrm{O}$. In vitro data by Zanella also indicated that micro-aspiration did not occur within $24 \mathrm{hrs}$ when PEEP was set at $15 \mathrm{cmH} 2 \mathrm{O}$, irrespective of which ETT type was investigated [25].

Lucangelo et al. evaluated the leakage of dye past the cuff in a bronchoscopy-controlled study in ventilated ICU patients [41]. The experiment lasted for $12 \mathrm{hrs}$. In the first $5 \mathrm{hrs}$ PEEP was maintained at $5 \mathrm{cmH} 2 \mathrm{O}$; thereafter PEEP was removed. In two on 40 patients leakage of dye occurred before removal of PEEP (5.0\%). After PEEP was removed, leakage became obvious in 37/40 patients (92.5\%). A single center trial, non-hypoxic mechanically ventilated patients were randomized to receive either 5-8 $\mathrm{cmH}_{2} 0$ PEEP $(n=66)$ or no PEEP $(n=65)$ [42]. VAP rate among patients ventilated with PEEP was $9.4 \%$ and significantly lower compared with the control group 
(25.4\%)(relative risk [RR] 0.37; 95\% CI 0.15-0.84). Of note, patients in the intervention group experienced less hypoxemia and there was no difference between the groups in rates of acute respiratory distress syndrome, barotrauma, or atelectasis. In the absence of particular contraindications, the use of at least $5 \mathrm{cmH}_{2} \mathrm{O}$ of PEEP can be recommended as standard in mechanically ventilated patients. In patients with overt right ventricular failure however, safety of external PEEP could be questioned. In these cases risks and benefits should be carefully considered.

\section{Semirecumbent position}

In 1999 Draculovic reported a lower risk of clinically suspected VAP (RR 0.23, 95\% CI 0.07-0.72) and microbiologically documented VAP (RR 0.22, 95\% CI 0.05-0.93) among patients cared for in semirecumbent positioning $\left(45^{\circ}\right.$ head-of-bed elevation) compared to patients kept in supine position $\left(0^{\circ}\right.$ head-of-bed elevation) [43]. Especially patients in the supine group receiving enteral nutrition experienced a high risk of VAP. Another randomized study comparing $45^{\circ}$ vs. $25^{\circ}$ head-of-bed elevation found a nonsignificant reduction (RR 0.38, 95\% CI 0.04-3.77) but the study was toughly underpowered (17 vs. 13 patients respectively) [44]. Both studies suffered several limitations such as prematurely stopping after interim analysis [43], high dropout rates [44], and uncertainties about diagnostic approaches $[43,44]$. In the Draculovic trial, correctness of patients' position was checked once daily, while Keeley et al. did not report posture checks. This is a serious flaw. van Niewenhoven et al. conducted a trial in which patients were randomly allocated to a $45^{\circ}$ vs. $10^{\circ}$ head-of-bed elevation [45]. Head-of-bed elevation was continuously monitored by means of a transducer with pendulum and a dedicated nurse controlled patients' position twice-to-thrice daily and restored to the target position (if possible). As $85 \%$ of the time semirecumbent $\left(45^{\circ}\right)$ positioning as not achieved, the study turned out to be a comparison between approximately $10^{\circ} \mathrm{vs} .28^{\circ}$ head-ofbed elevation. No difference in VAP risk was observed.

Although based on the results of a limited-quality trial, most recommendations agree that supine positioning is to be avoided [46]. However, it remains unproven whether $45^{\circ}$ head-of-bed elevation is superior to $25-30^{\circ}$ elevation. Despite the absence of a clear advantage, an expert panel recommended semirecumbent positioning weighting its potential benefits and harms [47]. Patients at risk for hemodynamic instability following $45^{\circ}$ headof-bed elevation may benefit from a $20-30^{\circ}$ backrest elevation [48].

\section{Monitoring gastric overdistention}

Gastric overdistention has been historically considered a risk factor for VAP as it is assumed to facilitate bacterial translocation from the stomach to the respiratory tract.
With enteral nutrition becoming standard of care in mechanically ventilated patients monitoring gastrointolerance to enteral feeding by checking residual volumes is frequent practice. Most frequent thresholds used to interrupt enteral feeding are residual volumes of 200$250 \mathrm{~mL}$ [49]. Yet, cessation of enteral feeding is not recommended unless residual volumes exceed $500 \mathrm{~mL}$ [50]. In addition, monitoring residual gastric volumes may increase the risk of inadequate caloric intake. The effect of not monitoring residual gastric volumes on risk of VAP was evaluated in a multicentre, randomized controlled trial [51]. VAP rate in the absence of monitoring residual volumes was $16.7 \%$ and $15.8 \%$ in the control group in which residual volumes were checked every $6 \mathrm{hrs}$ (and in which residual volumes greater than $250 \mathrm{~mL}$ were returned to the patient) (difference, $0.9 \%, 90 \% \mathrm{CI},-4.8$ $6.7 \%)$. No differences were observed between the groups regarding rates of other healthcare-associated infections, length of ventilator dependence, ICU stay, or mortality. Importantly, the proportion of patients receiving 100\% of their caloric intake target was significantly higher in the intervention group (odds ratio 1.77, 95\% CI, 1.252.51). As such, monitoring gastric overdistention seems not to benefit prevention of VAP.

\section{Interventions indirectly affecting the risk associated with microaspiration}

Some interventions do not directly target microaspiration. Their practice however, may alter the risk of microaspiration and/or pneumonia. Based on the available evidence their use can be either be advocated or not. Small bowel feedings, for example, are assumed to minimize the risk of aspiration should intolerance to enteral feedings occur. No data however to support this practice with the aim to reduce VAP risk are available. Routine changes of ventilator circuits do not decrease VAP risk. Even stronger, where no benefit is to be expected the patient may experience a microaspiration by unnecessary manipulation of the tubings.

Mouthwashes with chlorhexidine solutions and selective oral decontamination do not as such reduce the risk of microaspiration $[21,52]$. Yet, these interventions reduce the microbial burden in the oral cavity and therefore the inoculum of potential pathogenic microorganisms entering the lower respiratory tract in case of microaspiration.

\section{Conclusions}

Several interventions have been developed in order to reduce the risk of microaspiration and subsequently VAP. Taking into account the effectiveness of avoiding microaspiration and VAP the following measures should be considered: (i) the use of ETT designed for SSD, (ii) continuous cuff pressure monitoring and control, 
(iii) a minimum PEEP of $5 \mathrm{cmH}_{2} \mathrm{O}$, and (iv) avoidance of supine positioning. The following measures lack data to demonstrate their benefits in terms of VAP risk reduction, but are nevertheless interesting because of their potential to reduce microaspiration: (i) gel lubrication of the cuff prior to intubation, (ii) polyurethane cuffed ETTs, and (iii) taper-shaped ETT cuffs.

\section{Abbreviations}

Cl: Confidence interval; ETT: Endotracheal tube; ICU: Intensive care unit; PEEP: Positive end-expiratory pressure; PVC: Polyvinyl chloride; RR: Relative risk; SSD: Subglottic secretions drainage; VAP: Ventilator-associated pneumonia.

\section{Competing interests}

SB served as advisory board member for Covidien and received honoraria for lectures from from Covidien and Kimberley Clark. JP is member of a European advisory board of Covidien. MK received honoraria for lectures from Cardeas, Accelerate, and Merck.

\section{Authors' contributions}

All authors agreed on the focus and structure of the paper. SB conducted the literature search and drafted the first version of the manuscript, while JP and MK contributed substantially to the final version. All authors read and approved the final manuscript.

\section{Authors' information}

SB is Professor at the Dept. of Internal Medicine at Ghent University and holds a research mandate of the Special Research Fund at Ghent University. $J P$ is Professor and head of the Dept. of Anesthesiology \& Peri-Operative Medicine at University Hospital Brussels. MK is Golman Professor of Pulmonary and Critical Care Medicine at Washington University School of Medicine.

\section{Author details}

${ }^{1}$ Dept. of Internal Medicine, Faculty of Medicine \& Health Sciences, Ghent University, De Pintelaan 185, 9000 Ghent, Belgium. ${ }^{2}$ Burns, Trauma and Critical Care Research Centre, The University of Queensland, Brisbane, Australia. ${ }^{3}$ Dept. of Anesthesiology \& Perioperative Medicine, University Hospital Brussels, Laarbeeklaan 101, 1090 Brussels, Belgium. ${ }^{4}$ Division of Pulmonary and Critical Care Medicine, Washington University School of Medicine, 660 South Euclid Avenue, Campus Box 8052, St Louis, MO 63110, USA.

Received: 28 January 2014 Accepted: 28 February 2014

Published: 28 November 2014

\section{References}

1. Rello J, Ollendorf DA, Oster G, Vera-Llonch M, Bellm L, Redman R, Kollef MH: Epidemiology and outcomes of ventilator-associated pneumonia in a large US database. Chest 2002, 122(6):2115-2121.

2. Kollef MH, Hamilton CW, Ernst FR: Economic impact of ventilatorassociated pneumonia in a large matched cohort. Infect Control Hosp Epidemiol 2012, 33(3):250-256.

3. Leistner R, Kankura L, Bloch A, Sohr D, Gastmeier P, Geffers C: Attributable costs of ventilator-associated lower respiratory tract infection (LRTI) acquired on intensive care units: a retrospectively matched cohort study. Antimicrob Resist Infect Control 2013, 2(1):13.

4. Restrepo MI, Anzueto A, Arroliga AC, Afessa B, Atkinson MJ, Ho NJ, Schinner R, Bracken RL, Kollef MH: Economic burden of ventilatorassociated pneumonia based on total resource utilization. Infect Control Hosp Epidemiol 2010, 31(5):509-515.

5. Blot S, Koulenti D, Dimopoulos G, Martin C, Komnos A, Krueger WA Spina G, Armaganidis A, Rello J: Prevalence, Risk Factors, and Mortality for Ventilator-Associated Pneumonia in Middle-Aged, Old, and Very Old Critically III Patients. Crit Care Med 2013, 42(3):601-609.

6. Depuydt PO, Vandijck DM, Bekaert MA, Decruyenaere JM, Blot SI, Vogelaers DP, Benoit DD: Determinants and impact of multidrug antibiotic resistance in pathogens causing ventilator-associated-pneumonia. Crit Care 2008, 12(6):R142.
7. Myny D, Depuydt P, Colardyn F, Blot S: Ventilator-associated pneumonia in a tertiary care ICU: analysis of risk factors for acquisition and mortality. Acta Clin Belg 2005, 60(3):114-121.

8. Timsit JF, Zahar JR, Chevret S: Attributable mortality of ventilatorassociated pneumonia. Curr Opin Crit Care 2011, 17(5):464-471.

9. Dimopoulos G, Koulenti D, Blot S, Sakr Y, Anzueto A, Spies C, Violan JS, Kett D, Armaganidis A, Martin C, Vincent JL: Critically ill elderly adults with infection: analysis of the extended prevalence of infection in intensive care study. J Am Geriatr Soc 2013, 61(12):2065-2071.

10. Safdar N, Dezfulian C, Collard HR, Saint S: Clinical and economic consequences of ventilator-associated pneumonia: a systematic review. Crit Care Med 2005, 33(10):2184-2193.

11. Magill SS, Klompas M, Balk R, Burns SM, Deutschman CS, Diekema D, Fridkin S, Greene L, Guh A, Gutterman D, Hammer B, Henderson D, Hess DR, Hill DR, Horan T, Kollef M, Levy M, Septimus E, Vanantwerpen C, Wright D, Lipsett P: Developing a new, national approach to surveillance for ventilator-associated events. Am J Crit Care 2013, 22 (6):469-473

12. Labeau S, Vandijck D, Rello J, Adam S, Rosa A, Wenisch C, Backman C, Agbaht K, Csomos A, Seha M, Dimopoulos G, Vandewoude K, Blot SI: Evidence-based guidelines for the prevention of ventilator-associated pneumonia: results of a knowledge test among European intensive care nurses. J Hosp Infect 2008, 70(2):180-185.

13. Lambert ML, Palomar M, Agodi A, Hiesmayr M, Lepape A, Ingenbleek A, Palencia Herrejon E, Blot S, Frank U: Prevention of ventilator-associated pneumonia in intensive care units: an international online survey. Antimicrob Resist Infect Control 2013, 2(1):9.

14. Rello J, Lorente C, Bodi M, Diaz E, Ricart M, Kollef MH: Why do physicians not follow evidence-based guidelines for preventing ventilatorassociated pneumonia?: a survey based on the opinions of an international panel of intensivists. Chest 2002, 122(2):656-661.

15. Ricart M, Lorente C, Diaz E, Kollef MH, Rello J: Nursing adherence with evidence-based guidelines for preventing ventilator-associated pneumonia. Crit Care Med 2003, 31(11):2693-2696.

16. Labeau S, Vandijck DM, Claes B, Van Aken P, Blot SI: Critical care nurses' knowledge of evidence-based guidelines for preventing ventilatorassociated pneumonia: an evaluation questionnaire. Am J Crit Care 2007, 16(4):371-377

17. Nseir S, Zerimech F, Jaillette E, Artru F, Balduyck M: Microaspiration in intubated critically ill patients: diagnosis and prevention. Infect Disord Drug Targets 2011, 11(4):413-423.

18. Blot $S$, Vandijck D, Labeau S: Oral care of intubated patients. Clin Pulm Med 2008, 15(3):153-160

19. Schallom M, Tricomi SM, Chang YH, Metheny NA: A pilot study of pepsin in tracheal and oral secretions. Am J Crit Care 2013, 22(5):408-411.

20. Kress JP, Pohlman AS, O'Connor MF, Hall JB: Daily interruption of sedative infusions in critically ill patients undergoing mechanical ventilation. N Engl J Med 2000, 342(20):1471-1477.

21. Labeau SO, Van de Vyver K, Brusselaers N, Vogelaers D, Blot SI: Prevention of ventilator-associated pneumonia with oral antiseptics: a systematic review and meta-analysis. Lancet Infect Dis 2011, 11(11):845-854.

22. Safdar N, Crnich CJ, Maki DG: The pathogenesis of ventilator-associated pneumonia: its relevance to developing effective strategies for prevention. Respir Care 2005, 50(6):725-739. discussion 739-741.

23. Dullenkopf A, Gerber A, Weiss M: Fluid leakage past tracheal tube cuffs: evaluation of the new Microcuff endotracheal tube. Intensive Care Med 2003, 29(10):1849-1853.

24. Dave MH, Frotzler A, Spielmann N, Madjdpour C, Weiss M: Effect of tracheal tube cuff shape on fluid leakage across the cuff: an in vitro study. $\mathrm{Br} J$ Anaesth 2010, 105(4):538-543.

25. Zanella A, Scaravilli V, Isgro S, Milan M, Cressoni M, Patroniti N, Fumagalli R, Pesenti A: Fluid leakage across tracheal tube cuff, effect of different cuff material, shape, and positive expiratory pressure: a bench-top study. Intens Care Med 2011, 37(2):343-347.

26. Poelaert J, Depuydt P, De Wolf A, Van de Velde S, Herck I, Blot S: Polyurethane cuffed endotracheal tubes to prevent early postoperative pneumonia after cardiac surgery: a pilot study. J Thorac Cardiovasc Surg 2008, 135(4):771-776.

27. Mahmoodpoor A, Peyrovi-far A, Hamishehkar H, Bakhtyiari Z, Mirinezhad MM, Hamidi M, Golzari SE: Comparison of prophylactic effects of polyurethane cylindrical or tapered cuff and polyvinyl chloride cuff endotracheal 
tubes on ventilator-associated pneumonia. Acta Med Iran 2013, 51(7):461-466.

28. D'Haese J, De Keukeleire T, Remory I, Van Rompaey K, Umbrain V, Poelaert J: Assessment of intraoperative microaspiration: does a modified cuff shape improve sealing? Acta Anaesthesiol Scand 2013, 57(7):873-880.

29. Muscedere J, Rewa O, McKechnie K, Jiang X, Laporta D, Heyland DK: Subglottic secretion drainage for the prevention of ventilator-associated pneumonia: A systematic review and meta-analysis. Crit Care Med 2011 39(8):1985-1991.

30. Lacherade JC, De Jonghe B, Guezennec P, Debbat K, Hayon J, Monsel A, Fangio P, Appere De Vecchi C, Ramaut C, Outin H, Bastuji-Garin S: Intermittent subglottic secretion drainage and ventilator-associated pneumonia: a multicenter trial. Am J Respir Crit Care Med 2010, 182(7):910-917.

31. Blunt MC, Young PJ, Patil A, Haddock A: Gel lubrication of the tracheal tube cuff reduces pulmonary aspiration. Anesthesiology 2001, 95(2):377-381.

32. Dave MH, Koepfer N, Madjdpour C, Frotzler A, Weiss M: Tracheal fluid leakage in benchtop trials: comparison of static versus dynamic ventilation model with and without lubrication. J Anesth 2010, 24(2):247-252

33. Lizy C, Swinnen W, Labeau S, Poelaert J, Dulhunty J, Vogelaers D, Vandewoude K, Blot S: Cuff pressure of endotracheal tubes after changes in body position in critically ill patients treated with mechanical ventilation. Am J Crit Care 2014, 23(1):e1-e8.

34. Sole ML, Su X, Talbert S, Penoyer DA, Kalita S, Jimenez E, Ludy JE, Bennett M: Evaluation of an intervention to maintain endotracheal tube cuff pressure within therapeutic range. Am J Crit Care 2011, 20(2):109-118.

35. Valencia M, Ferrer M, Farre R, Navajas D, Badia JR, Nicolas JM, Torres A: Automatic control of tracheal tube cuff pressure in ventilated patients in semirecumbent position: a randomized trial. Crit Care Med 2007, 35(6):1543-1549.

36. Nseir S, Zerimech F, Fournier C, Lubret R, Ramon P, Durocher A, Balduyck M: Continuous control of tracheal cuff pressure and microaspiration of gastric contents in critically ill patients. Am J Respir Crit Care Med 2011, 184(9):1041-1047.

37. Lorente L, Blot S, Rello J: New issues and controversies in the prevention of ventilator-associated pneumonia. Am J Respir Crit Care Med 2010, 182(7):870-876.

38. Guyton D, Banner MJ, Kirby RR: High-volume, low-pressure cuffs. Are they always low pressure? Chest 1991, 100(4):1076-1081.

39. Ouanes I, Lyazidi A, Danin PE, Rana N, Di Bari A, Abroug F, Louis B, Brochard L: Mechanical influences on fluid leakage past the tracheal tube cuff in a benchtop model. Intens Care Med 2011, 37(4):695-700.

40. Pitts R, Fisher D, Sulemanji D, Kratohvil J, Jiang Y, Kacmarek R: Variables affecting leakage past endotracheal tube cuffs: a bench study. Intensive Care Med 2010, 36(12):2066-2073.

41. Lucangelo U, Zin WA, Antonaglia V, Petrucci L, Viviani M, Buscema G, Borelli M, Berlot G: Effect of positive expiratory pressure and type of tracheal cuff on the incidence of aspiration in mechanically ventilated patients in an intensive care unit. Crit Care Med 2008, 36(2):409-413.

42. Manzano F, Fernandez-Mondejar E, Colmenero M, Poyatos ME, Rivera R, Machado J, Catalan I, Artigas A: Positive-end expiratory pressure reduces incidence of ventilator-associated pneumonia in nonhypoxemic patients. Crit Care Med 2008, 36(8):2225-2231.

43. Drakulovic MB, Torres A, Bauer TT, Nicolas JM, Nogue S, Ferrer M: Supine body position as a risk factor for nosocomial pneumonia in mechanically ventilated patients: a randomised trial. Lancet 1999, 354(9193):1851-1858.

44. Keeley $L$ : Reducing the risk of ventilator-acquired pneumonia through head of bed elevation. Nurs Crit Care 2007, 12(6):287-294.

45. van Nieuwenhoven CA, Vandenbroucke-Grauls C, van Tiel FH, Joore HC, van Schijndel RJ, van der Tweel I, Ramsay G, Bonten MJ: Feasibility and effects of the semirecumbent position to prevent ventilator-associated pneumonia: a randomized study. Crit Care Med 2006, 34(2):396-402.

46. Lorente L, Blot S, Rello J: Evidence on measures for the prevention of ventilator-associated pneumonia. Eur Respir J 2007, 30(6):1193-1207.

47. Niel-Weise BS, Gastmeier P, Kola A, Vonberg RP, Wille JC, van den Broek PJ: An evidence-based recommendation on bed head elevation for mechanically ventilated patients. Crit Care 2011, 15(2):R111.

48. Gocze I, Strenge F, Zeman F, Creutzenberg M, Graf BM, Schlitt HJ, Bein T: The effects of the semirecumbent position on hemodynamic status in patients on invasive mechanical ventilation: prospective randomized multivariable analysis. Crit Care 2013, 17(2):R80.

49. Metheny NA, Mills AC, Stewart BJ: Monitoring for intolerance to gastric tube feedings: a national survey. Am J Crit Care 2012, 21(2):e33-e40.

50. McClave SA, Martindale RG, Vanek WW, McCarthy M, Roberts P, Taylor B, Ochoa JB, Napolitano L, Cresci G: Guidelines for the Provision and Assessment of Nutrition Support Therapy in the Adult Critically III Patient: Society of Critical Care Medicine (SCCM) and American Society for Parenteral and Enteral Nutrition (A.S.P.E.N.). JPEN J Parenter Enteral Nutr 2009, 33(3):277-316.

51. Reignier J, Mercier E, Le Gouge A, Boulain T, Desachy A, Bellec F, Clavel M, Frat JP, Plantefeve G, Quenot JP, Lascarrou JB: Effect of not monitoring residual gastric volume on risk of ventilator-associated pneumonia in adults receiving mechanical ventilation and early enteral feeding: a randomized controlled trial. JAMA 2013, 309(3):249-256.

52. de Smet AM, Kluytmans JA, Cooper BS, Mascini EM, Benus RF, van der Werf TS, van der Hoeven JG, Pickkers P, Bogaers-Hofman D, van der Meer NJ, Bernards AT, Kuijper EJ, Joore JC, Leverstein-van Hall MA, Bindels AJ, Jansz AR, Wesselink RM, de Jongh BM, Dennesen PJ, van Asselt GJ, te Velde LF, Frenay IH, Kaasjager K, Bosch FH, van Iterson M, Thijsen SF, Kluge GH, Pauw W, de Vries JW, Kaan JA, et al: Decontamination of the digestive tract and oropharynx in ICU patients. N Engl J Med 2009, 360(1):20-31.

doi:10.1186/1471-2334-14-119

Cite this article as: Blot et al:: How to avoid microaspiration? A key element for the prevention of ventilator-associated pneumonia in intubated ICU patients. BMC Infectious Diseases 2014 14:119.

\section{Submit your next manuscript to BioMed Central and take full advantage of:}

- Convenient online submission

- Thorough peer review

- No space constraints or color figure charges

- Immediate publication on acceptance

- Inclusion in PubMed, CAS, Scopus and Google Scholar

- Research which is freely available for redistribution

Submit your manuscript at www.biomedcentral.com/submit
C Biomed Central 